\title{
Is Brazil a Geoeconomic Node? Geography, Public Policy, and the Failure of Economic Integration in South America
}

\author{
Sören Scholvin 1 \\ https://orcid.org/0000-0001-5911-2718 \\ Andrés Malamud ${ }^{2}$ \\ https://orcid.org/0000-0001-8838-1650
}

1University of Hanover, Institute of Economic and Cultural Geography, Hanover,
Germany
2Universidade de Lisboa, Instituto de Ciências Sociais, Lisboa, Portugal

Brazil has been labeled an anchor country, a leading area, and a regional power. Yet, even before the crisis triggered by Operation 'Car Wash' began, several scholars had called into question Brazil's driving role in regional integration, stressing political challenges and economic weaknesses that hindered closer relationships among the South American countries. More optimistic research tends to concentrate on initiatives and visions of Brazil's regional leadership, with lesser focus on obstacles and implementation. We develop the concept of 'geoeconomic nodality' to assess Brazi's impact on South America and shed light on the structural sources of economic fragmentation, namely geographical conditions and their interaction with public policies. A geoeconomic node is the core of economic networks in a geographically delimited system. The flows of the system's units are focused on the node, enabling it to transfer impulses for development - and reflecting what the concepts on anchor countries, leading areas, and regional powers suggest. Our findings show that long distances, physical barriers, the maritime orientation of core zones of population and economic activity, and the poor state of transcontinental infrastructure reduce Brazil's geoeconomic nodality. Resource nationalism, volatile public policies, and fluctuating exchange rates contribute to this structural mix, so that the prospects to overcome the obstacles imposed by geography appear dim.

Keywords: Geoeconomics; regional integration; regional power; Brazil; South America.

http://doi.org/ 10.1590/1981-3821202000020004

For data replication, see: https://doi.org/10.7910/DVN/HHKRN0

Correspondence: Andrés Malamud.E-mail: amalamud@ics.ulisboa.pt

This publication is registered under a CC-BY Licence. 
$\mathrm{T}$ he World Bank (2009) suggests that developing countries attach themselves to nearby emerging economies - 'leading areas' in its terminology - so as to benefit from momentum for development. The concept of 'anchor countries' has been coined to identify these emerging economies - for example Brazil, India, and South Africa - as regional growth engines (STAMM, 2004). Nolte (2010) argues that 'regional powers' shape regions of (sub)continental scope. States so defined are economic cores tied to their regional peripheries through production and trade, both dominating their neighboring countries but also fostering their development (KAPPEL, 2012).

Despite their minor differences, these concepts are based on the assumption that some countries are decisive for the economic prospects of entire (sub)continents. Such an assumption has been widely applied to Brazil's role in South America. This country, the argument goes, has become capable of "contributing to the development of others, mainly in its own region" (RAMANZINI JR. and MARIANO, 2018, p. 235, our translation). Pinheiro and Gaio (2014) suggest that Brazil has acted as regional leader because of its commitment to development in South America. Lima and Hirst argue that under President Lula da Silva, Brazil "laid great emphasis on the expansion of business relations" (LIMA and HIRST, 2006, pp. 30-31) with its neighboring countries - seeking to promote a developmentalist agenda for the region. During the Lula era, Brazil tried "to bridge political and ideological cleavages by guiding the states of the region towards the shared goal of a South American space" (FLEMES, 2010, p. 109), taking the lead in collaboration on economic and security issues.

However, these scholars provide little evidence that the rhetoric on regional cooperation and integration is matched by a concrete economic impact. Their research generates important insights on agency, but it mostly neglects structure, particularly regarding connectivity among the South American countries. At first glance, it seems that Brazil is a typical leading area, anchor country, and regional power: it is the top trading partner of Argentina, Bolivia, Paraguay, and Uruguay (Figures 01 and 02); it has been the leading promoter of the Initiative for the Integration of the Regional Infrastructure of South America (IIRSA); and its National Development Bank (BNDES) has 
supported the internationalization of Brazilian firms throughout the region. Brazil's political ambitions reach beyond the Southern Cone, as exemplified by its role in the establishment of the Union of South American Nations (UNASUR) in 2008

Yet, some scholars have voiced skepticism regarding Brazil's influence and impact on South America (BURGES, 2005; DOCTOR, 2013; MALAMUD, 2011, 2005; MALAMUD and GARDINI, 2012; SPEKTOR, 2010). We contribute to this debate by offering a perspective from political geography. This allows us to assess de facto interaction (instead of mere declarations and initiatives). It also sheds light on a usually overlooked factor: the impact of geographical conditions upon the relationships between Brazil and its neighboring countries, especially regarding what we call 'geoeconomic nodality'.

A geoeconomic node is the core of economic networks in a geographically delimited system. The flows of all units that are part of the system are focused on the node, enabling it to transfer momentum for development. Geoeconomic nodality is a sine-qua-non condition for anchor countries, leading areas, and regional powers to exist at all, and for regional integration to progress.

The concept of geoeconomic nodality leads to an assessment of structure, not agency. We are not saying that studies that deal with agency - revealing, for example, how different interest groups shape Brazil's approach toward the region (CASON and POWER, 2009) or how Brazil strategically defects from leading integration (KRAPOHL, 2019) - are without merit. On the contrary, we acknowledge that agency influences some geographical conditions in the long run. It is important for public policies, which our analysis covers too. However, an analysis of geoeconomic nodality should shed light on aspects neglected by mainstream research, thus complementing the state of the art.

The time-sensitive data of our analysis concentrates on the period from 2008 to 2017, which arguably displays the arc of Brazil's regional influence from zenith to nadir. By chance - or not - it also coincides with the life span of UNASUR, from its foundation to its abandonment by most member states.

This article consists of five sections. First, we summarize the literature on emerging economies and regional development, with particular regard to Brazil, and introduce the defining features of geoeconomic nodality. Second, we examine 
regional patterns of trade and investment so as to capture Brazil's nodality. Third, we analyze the impact of location and physical barriers on the relations between Brazil and the rest of South America. Fourth, we assess the state of the region's infrastructure for energy and transport. Fifth, we explain how public policies have influenced Brazil's prospects as a geoeconomic node, and then offer conclusions.

\section{Conceptual framework}

The term anchor country encompasses emerging economies that play a central role in the development of regions of (sub)continental scale. The criterion that determines whether a state is an anchor country is its share of the regional economic output. Anchor countries are supposed to be economically more diversified and to possess a share of industrial production above the average of the Global South. As a consequence, they are more competitive than other developing countries and serve as regional growth engines: prosperity in anchor countries is expected to lead to regional prosperity; recession in anchor countries to regional recession (STAMM, 2004).

The World Bank (2009) has advanced a similar understanding in its World Development Report. It labels countries that are economically more developed than their surroundings as leading areas - Brazil and South Africa, for example. The key argument is that leading areas offer a high density of economic activity, and developing countries have to reduce distance and division vis-àvis leading areas so as to benefit from this density. Spatial disparities will eventually decrease due to economic impulses generated by leading areas. Remote areas cannot be successful in isolation: their development requires links to the greater national and (sub)continental economy.

Research on regional powers starts with the idea that these states are influential (ØSTERUD, 1992). To qualify as a regional power, a state must be closely linked to its region in cultural, economic, and political ways (NOLTE, 2010). Hence, regional connectivity, which is a mere assumption in the anchor-country concept, becomes a condition for regional powers. Sometimes, this defining feature has been reduced to a criterion "for distinguishing and classifying different types of 
regional powers" (FLEMES and NOLTE, 2010, p. 07). Yet, if a regional power is not closely linked to its neighbors, why should one expect it to have an impact on them?

We show that regional connectivity is one of Brazil's key shortcomings. Brazil does not serve as a geoeconomic node of South America because it hardly connects with many of its neighboring countries. Research on the political economy of regional powers stresses the relevance of such connectivity. Kappel (2012) argues that regional powers achieve dominance over other states through unbalanced trade relations, the provision of capital, goods, and services. Regional powers are industrial cores. Sophisticated production is concentrated there, whereas more basic and standardized production is relocated to the regional peripheries. Regional powers are thus tied to their spheres of influence in value chains that allow for regionally dispersed and integrated production.

So how do the three concepts - anchor countries, leading areas, and regional powers - apply to Brazil? Basic trade data, IIRSA, and political commitment suggest that Brazil has played an important role in South America. The country accounts for about 50 percent of the regional economic output. Others - mainly Argentina in the automotive sector - are bound to the Brazilian economy in value chains. Their prosperity depends on Brazil's. The mid-2000s were marked by considerable efforts toward institution building within the Common Market of the South (Mercosur), especially to allow for developmental cooperation (RAMANZINI JR. and MARIANO, 2018; RIGGIROZZI and TUSSIE, 2012). Saraiva (2010) argues that economic and political integration in South America has been critical to Brazil for decades, as it guarantees foreign political autonomy visà-vis the United States and creates a fundament for Brazil's global aspirations. At least prior to the end of Dilma Rousseff's presidency, Brazil did indeed pursue a proactive regional agenda, as summarized by Lima (2014). Against the backdrop of these developments, Milani, Pinheiro and Lima (2017) advance the concept of 'graduation', arguing that the rise of states such as 
Brazil comes along with a shift from an orientation to the Global North to deeper regional integration that follows a long-term vision 1 .

We contend that the features above are insufficient to ascribe an outstanding relevance to Brazil as the three aforementioned concepts do. Much research on Brazil's role in South America is limited to declarations on interstate cooperation and integration initiatives. An analysis of whether such rhetoric translates into reality is often lacking. This shortcoming is exemplified by Palestini and Agostinis (2015), who claim that the South American states have successfully cooperated on transport infrastructure, but they fall short of showing impacts on regionalization. They mostly summarize how much has been spent on how many projects within the portfolio of UNASUR's Council on Infrastructure and Planning (COSIPLAN) that subsumed IIRSA in 2011.

Admittedly, a considerable number of projects have been implemented. This does not say much about effective integration, however. None of COSIPLAN/IIRSA's axes, which crisscross South America and frame the individual projects, is a neatly integrated corridor comparable to the First Transcontinental Railroad in the US or Russia's Trans-Siberian Railroad. Each axis consists of local projects: the bituminization of a road along a few dozen kilometers, the construction of a regional airport or the upgrading of a border post. Eighty-three percent of IIRSA's projects are single-country projects. Bilateral projects reach 16 percent, and only one percent is multilateral (COSIPLAN, 2017). The Inter-American Development Bank (IADB, 2008) concludes that the dominance of single-country projects has kept IIRSA from fulfilling its mandate to foster regional integration.

Against the backdrop of regional cooperation being more rhetoric than reality, regional integration had come to a dead end even before Brazil's present economic and political crisis began ${ }^{2}$. Burges (2005) refers to the low level of

\footnotetext{
${ }^{1}$ Milani, Pinheiro and Lima (2017) also refer to the global scale, where graduated powers become rule makers. We limit our analysis to the regional level.

${ }^{2}$ Here and further below, we refer to the sharp decline of Brazil's GDP growth rate, with the economy contracting in 2015 and 2016. The related political crisis brought about the impeachment of President Rousseff, the interim Temer presidency, and the tense 2018 election, which led to the controversial Bolsonaro presidency.
} 
intraregional trade and argues that South America lacks a business sector like the European one that could be the driver of deeper integration. Taking up Mattli's idea that regional integration depends on leading powers that not only coordinate policies but also "ease distributional tension by acting as [...] 'paymasters"' (MATTLI, 1999, p. 04), Malamud (2011, 2005) highlights that Brazil does not contribute disproportionately to regional integration. Doctor (2013) shows that economic asymmetries and institutional deficits hamper deepening integration in Mercosur. Malamud and Gardini (2012) suggest that regionalism has peaked and delivers diminishing returns. Spektor (2010) argues that already during the proactive Lula era, Brazil preferred regional cooperation to remain fragile and minimalist.

These problems have been reinforced by the more recent economic downturn and political instability. Suffering from severe budget constraints, Brazil could hardly make the necessary financial contribution to regional integration today, regardless of the fact that doing so is not on the agenda of President Jair Bolsonaro, who appears to have little interest in Mercosur - except for its role as an instrument for a trade agreement with the European Union.

All of the above are economic and political challenges to Brazil's role as an anchor country, leading area, and regional power. Debates on Brazil's role in South America would also benefit from recognizing the relevance of geography especially because an analysis of geographical constraints highlights the tremendous gap between the rhetoric and reality of regional integration and development (MALAMUD, 2018). Geographical factors interact with public policies (both being conditions or independent variables) to determine the economic impact of Brazil on the region (which is the outcome or dependent variable). In order to uncover this causal relationship, this article focuses on Brazil's prospects as a geoeconomic node.

Among the publications we have reviewed, only Viola and Lima (2017) mention geographical conditions. They point out that physical barriers such as the Andes and poor transport infrastructure obstruct regional value chains in South America, whereas the ease of maritime transport favors them in Southeast Asia. Unfortunately, the two authors do not go into details. As a side note, the gravity model - widely used by economists who study regional integration such as 
Bown et al. (2017) and Frankel, Stein and Wei (1995) - is based on distance as an independent variable. According to this model, the intensity of bilateral trade is expected to correspond to the size of the gross domestic product of the countries in consideration and distance between them. However, such research often applies a simplistic understanding of distance, measuring it in Euclidean terms - how many kilometers country A and B are apart. We conceptualize distance in a more complex and thus more realistic way. For example, Colombia is not economically close to Brazil, although they share a common border. Euclidean distance between Brasília and La Paz may be relatively low, but the two cities are further apart than, for instance, Seoul and Singapore are.

Our analytical framework derives from the lifework of the political geographer Saul Cohen. Cohen's (1963) analyses begin with an investigation of location and physical barriers. For instance, he points out that after the AdamsOnís Treaty signed by Spain and the US in 1819, Florida remained a peripheral part of the US for several decades, marked by swamps hindering any kind of development. The peninsula blocked rather than enabled the US expansion into the Caribbean. Cohen (1963) also examines core areas of population and economic activity as well as the connections between them, contextualizing these phenomena with regard to location and physical barriers: Florida turned into a stepping stone for the US into the Caribbean when infrastructure was built there and population density increased.

In this sense, Cohen's research revolves around "the interaction between, on the one hand, geographical settings [...] and, on the other, political processes" (2009, p. 12). He sees the "differentiated political space" as a result of the interplay "between the physical and the cultural [meaning man-made] environment" (COHEN, 1957, p. 05). Further to that, Florida's role in the US expansion into the Caribbean exemplifies that political space is "shaped by two forces - the centrifugal and the centripetal" (COHEN, 2009 , p. 34), with the former driving separation between territories and the latter promoting territorial unity. Centrifugal and centripetal forces comprise both naturally given and man-made geography. In other words, states shape their own 
material surroundings to a certain extent - for instance by building infrastructure to overcome physical barriers.

Cohen's position holds geography as a holistic science that covers all factors that matter, including many that political scientists associate with constructivist and institutionalist theories of international relations. Ours, meanwhile, is an approach that narrows the analytical scope down to material conditions that exist in geographic space. Rephrasing the conditions central to Cohen, our analysis focuses on four determinants of geoeconomic nodality: 01. location, distance, and physical barriers, as fundamental factors that provide a first indication of the extent to which a region can be tied to a geoeconomic node; 02 . the distribution of the population and economic activity, which impinges on the cohesion of a region and thus on geoeconomic nodality; 03. infrastructure for energy and transport, which constitutes the key manmade, centripetal force that helps to overcome distance and physical barriers; and 04. public policies, which condition the impact of the aforementioned determinants by boosting or hampering geoeconomic nodality.

Brazil's prospects as a geoeconomic node are also influenced by economics, most importantly foreign trade structures. The South American countries are mainly exporters of raw materials. Europe, the Far East, and North America - but not South America - are attractive markets for them (SCHOLVIN and MALAMUD, 2014). Brazil's economy has seen a revival of the primary sector because of increasing exports of commodities to China (JENKIS, 2012). Nevertheless, Brazil's industrial and services sectors grew until the current crisis. Its economy is diversified, providing opportunities for intraregional trade. Realizing such opportunities depends on overcoming geographical obstacles and adequate public policies being in place.

\section{Brazil's geoeconomic nodality}

\section{Economic ties}

A pre-crisis survey of Brazil's largest transnational companies revealed that each of the most internationalized among them - for instance Banco do Brasil, Odebrecht, and Vale - were present in five to eight South American countries. These enterprises were (and still are) also active in numerous Asian, European 
and, to a lesser extent, African countries. Moderately internationalized, large companies appear to focus on South America: eight of the thirteen foreign countries where Petrobras operated in 2011 were South American; even eight out of nine in the case of the construction company Tigre. If one counts the mere physical presence abroad, and thus disregards the profitability and volume of business activities, South America accounted for 31 percent of the foreign activities of Brazil's largest companies prior to the crisis significantly more than Europe (21 percent) and Asia (17 percent) (FUNDAÇÃO DOM CABRAL, 2011).

Because of its rapid economic development until 2014, Brazil held the capacity - and partly applied it - to advance large-scale, strategic projects in South America, for example transport infrastructure built by Andrade Gutierrez or Odebrecht. Brazilian construction companies received considerable subsidies from the BNDES for such projects. At least 35 percent of these credits had to be spent on inputs from Brazil. Mercosur's structural cohesion fund FOCEM was another means through which Brazil supported infrastructure projects in South America, at least in economically better times (PINHEIRO and GAIO, 2014). However, in addition to the aforementioned shortcomings of IIRSA's projects, not everything financed by the BNDES contributes to regional integration: for example, Odebrecht benefited from such credits provided for the expansion of the subway network of Caracas.

Counter intuitively, the involvement of Brazilian firms abroad has increased in the course of the last years. This does not apply to all Brazilian companies, but there appear to be many that rely on foreign markets - in Europe, the Far East, and the Americas - because these offer better prospects than Brazil's stagnating domestic market (O GLOBO, 2018a). This form of internationalization of Brazilian firms, which does give a boost to their presence in the neighboring countries, is market-seeking, however. Instead of establishing value chains that would tie the South American economies together, Brazilian investors have set up subsidiaries that source, produce and sell in separate national markets. A study by the Economic Commission for Latin America and the Caribbean (ECLAC, 2006) makes the same point: Brazilian enterprises have established branch plant 
operations throughout the region so as to circumvent market access restrictions (or, in less frequent cases, to access resources for consumption in Brazil). Efficiency and strategic asset seeking, which would result in sophisticated regional value chains, remain marginal.

Brazil increasingly participates in global value chains as an exporter of primary-sector goods, rather than fostering regional value chains that would drive industrialization. According to figures provided by Viola and Lima (2017), manufacturing accounts for not much more than 10 percent of the Brazilian GDP (down from 16 to 18 per cent in the second half of the 2000s) and slightly less than 40 percent of all exports (down from a peak of almost 60 percent at the beginning of this century). The two authors furthermore point out that Brazil is a closed economy - measured by the share of exports in GDP and the share of foreign valueadded in gross exports. The latter stands at 11 percent, as compared to a global average of 24 percent.

Brazil does serve as a considerable supplier to the region, which becomes apparent in trade in automobiles and electronics - more than half of Brazil's corresponding exports go to South America (KAMIYA, 2014) ${ }^{3}$. Because of its closed economy, Brazil is not, however, a major importer in the regional context. Production inputs are domestic or from overseas (IAPADRE AND TAJOLI, 2014). Chen and De Lombaerde (2014) also find that Brazil has increased its exports to the region but not its imports therefrom. Regional value chains as a driver of industrialization should follow a reverse pattern, with the geoeconomic node being fed by production inputs - that is, intermediary goods - from the region, further processing and then exporting them globally.

Such a hub - linked to the spokes via backward linkages - would be necessary for South America to copy the Far Eastern model of development through regional value chains, which is based on intensive trade in manufactured intermediary goods. Chen and De Lombaerde (2011), among others, argue that

\footnotetext{
${ }^{3}$ As a side note, these exports are manufactured by foreign affiliates established in Brazil to assess the South American markets, suggesting that Brazil serves as a gateway to the region in some value chains.
} 
Brazil is at least a candidate in this regard, possibly serving as a dual hub together with Argentina. Such a vision is, however, still far from reality.

The regional activities of Petrobras exemplify these limits to Brazil's role as a geoeconomic node. Petrobras is the major buyer of natural gas from Bolivia. This is pure resource-seeking investment. Before Brazil's current crisis, the partly state-owned giant realized the main share of its international oil production in South America: 75 out of 148 million barrels a day in 2013; up from 19 out of 53 million in 2000 but down from a peak of 123 out of 144 million in 2006. Petrobras's exploitation of natural gas, which is almost exclusively South America, increased from 1.7 million cubic meters (cbm) a day in 2000 to 15.1 million in 2013 (Petrobras, 2013b). Since 2014, Petrobras has disinvested from Argentina, Colombia, and Peru. This is not only the result of the financial crisis of the Brazilian giant. As a former executive of Petrobras Argentina explained in a personal conversation with us, the company had earlier decided to concentrate on the Brazilian pre-salt resources - a decision whose magnitude was reinforced by the corruption scandal, which practically cut Petrobras off from international credit markets. Petrobras hence sold its assets abroad in order to be able to invest in Brazil4.

Further to that, Brazil's role as a geoeconomic node must be spatially delineated in a precise way. The literature on Brazil as an anchor country, leading area and regional powers refers to South America, as do Brazil's official foreign policy documents, so we follow suit. As Figure 01 and 02 show, Brazil is an important trading partner of the countries of the Southern Cone, with the exception of Chile. In particular Argentina and Paraguay trade intensively with Brazil; so does Bolivia with regard to its exports. The ongoing crisis appears to have only affected Argentinean and Bolivian exports to Brazil, but some caution is needed because the absolute foreign trade of several regional countries fluctuates considerably, complicating the interpretation of relative figures. Table 01 reveals that Colombia, Ecuador, Guyana, and Venezuela are economically much closer to the US. China is the most important trading partner of Chile and Peru 5 .

4Personal conversation with a former executive of Petrobras Argentina, Buenos Aires, 10 June 2016.

${ }^{5}$ The literature that applies the gravity model to intraregional trade, especially Bown et al. (2017), contradicts this interpretation because trade among the South American countries is slightly more than the model predicts. What matters to this article however is that our benchmark - the concepts of anchor countries, leading areas, and regional powers - leads to different expectations. Revisiting these concepts against the backdrop of the gravity model is an interesting endeavor for a different article. 
Table 01. Share of China and the US in the foreign trade of the regional countries

\begin{tabular}{lllll}
\hline & $\begin{array}{l}\text { Share of China in } \\
\text { total exports }\end{array}$ & $\begin{array}{l}\text { Share of China in } \\
\text { total imports }\end{array}$ & $\begin{array}{l}\text { Share of the US in } \\
\text { total exports }\end{array}$ & $\begin{array}{l}\text { Share of the US in } \\
\text { total imports }\end{array}$ \\
\hline Argentina & $7.5 \%$ & $18.5 \%$ & $7.9 \%$ & $11.3 \%$ \\
Bolivia & $5.1 \%$ & $21.7 \%$ & $7.8 \%$ & $8.4 \%$ \\
Chile & $27.5 \%$ & $23.9 \%$ & $14.5 \%$ & $18.1 \%$ \\
Colombia & $5.1 \%$ & $19.3 \%$ & $28.5 \%$ & $26.3 \%$ \\
Ecuador & $4.0 \%$ & $15.4 \%$ & $31.5 \%$ & $22.8 \%$ \\
Guyana & marginal & $8.9 \%$ & $16.5 \%$ & $26.5 \%$ \\
Paraguay & marginal & $31.3 \%$ & marginal & $7.4 \%$ \\
Peru & $26.5 \%$ & $22.3 \%$ & $15.2 \%$ & $20.1 \%$ \\
Suriname & marginal & $7.6 \%$ & marginal & $30.6 \%$ \\
Uruguay & $19.0 \%$ & $20.0 \%$ & $5.7 \%$ & $10.9 \%$ \\
Venezuela & $16.0 \%$ & $14.2 \%$ & $34.8 \%$ & $24.8 \%$ \\
\hline
\end{tabular}

Source: Central Intelligence Agency (2018).

Note: Data is for 2017.

Figure 01. Share of exports to Brazil in the total exports of the regional countries

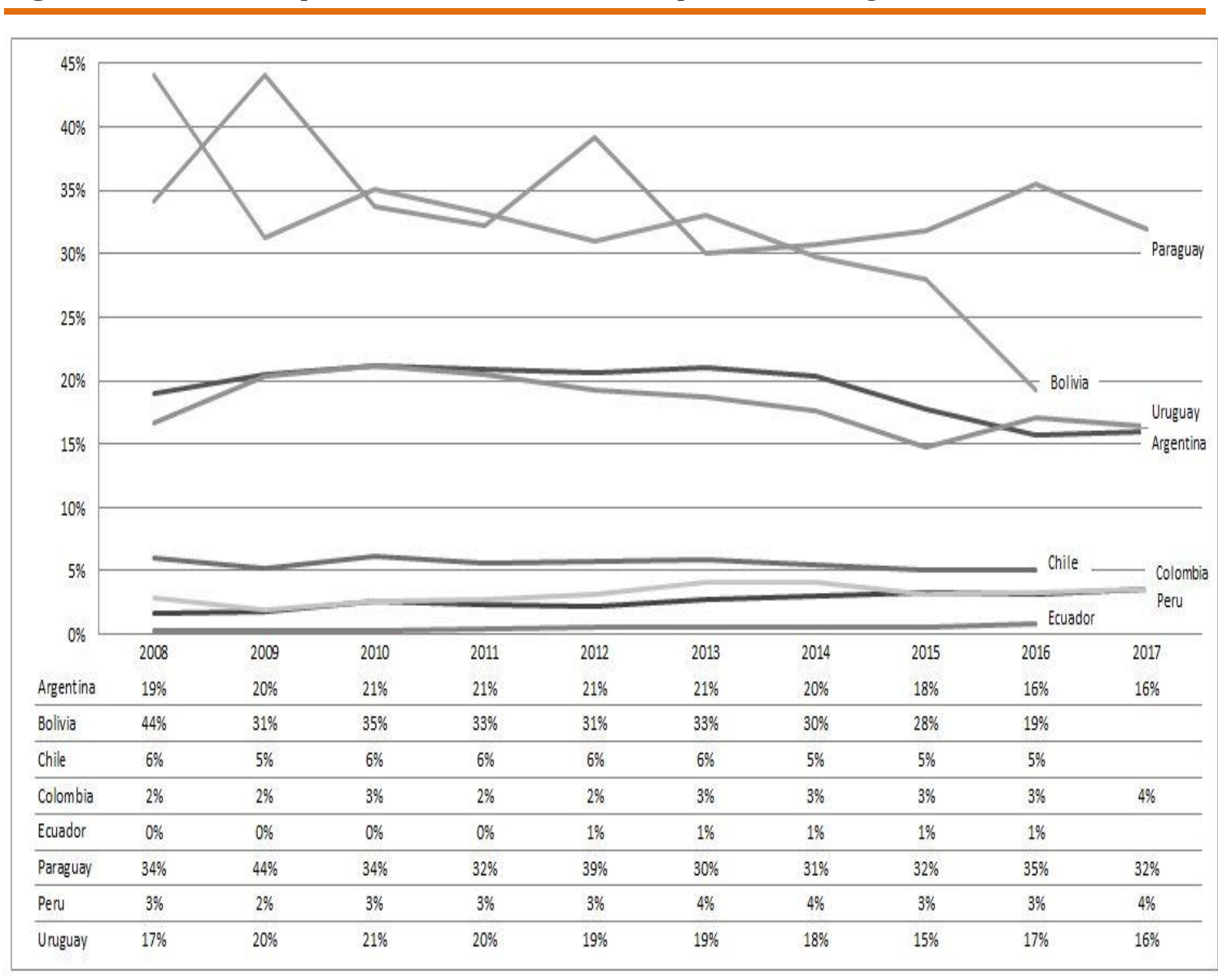

Source: IADB (2018).

Notes: Since rounded values are shown, 0 percent means that the respective share is smaller than 0.5 percent. Guyana has been excluded for better visualization. Brazil reached a share of 0.4 percent in Guyana's exports in 2017. Data on Suriname is incomplete, but Brazil's share in Suriname's exports stood at 0.2 and 0.7 percent in 2014 and 2015 respectively. The IADB's data on Venezuela's foreign trade does not specify the shares of single countries therein. 
Figure 03 shows that as a source of foreign direct investment, Brazil plays a considerable role for Paraguay and Uruguay. Whereas its relevance for Paraguay increased tremendously from 2010 until 2017, Brazil lost its dominance as a source of FDI for Uruguay during the same time frame. Brazilian FDI plays a marginal role in Argentina. It has lost much relevance in Peru and gained some in Venezuela, probably because there are few companies that would invest in the latter country at the moment. For the remaining regional countries, Brazilian FDI is irrelevant.

Figure 02. Share of imports from Brazil in the total imports of the regional countries

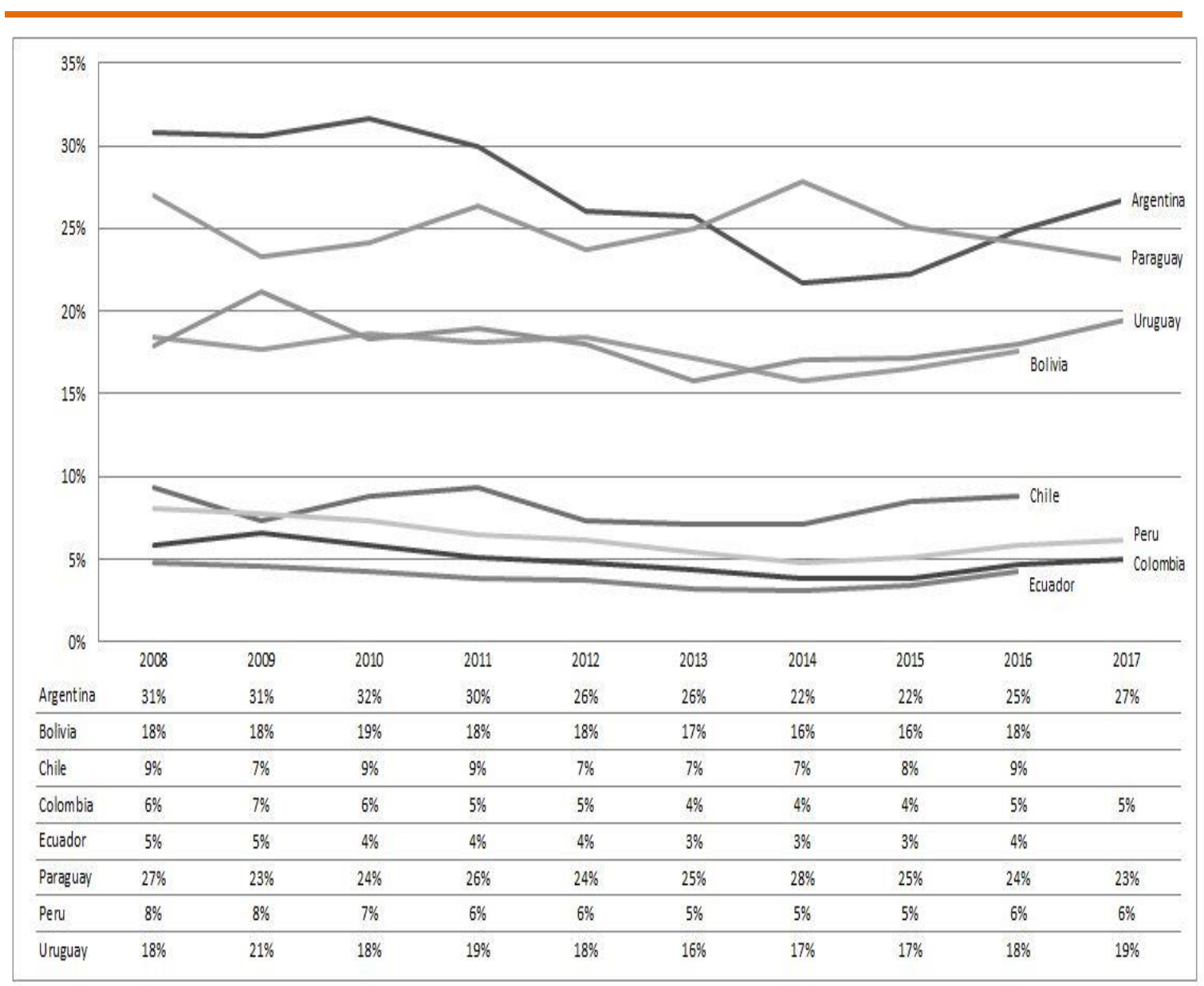

Source: IADB (2018).

Notes: Brazil reached a share of 1.5 percent in Guyana's imports in 2017. Brazil's share in Suriname's imports declined from 3.2 percent in 2011 to 1.9 percent in 2015. 
Figure 03. Brazil's share of the inward FDI stock of the regional countries

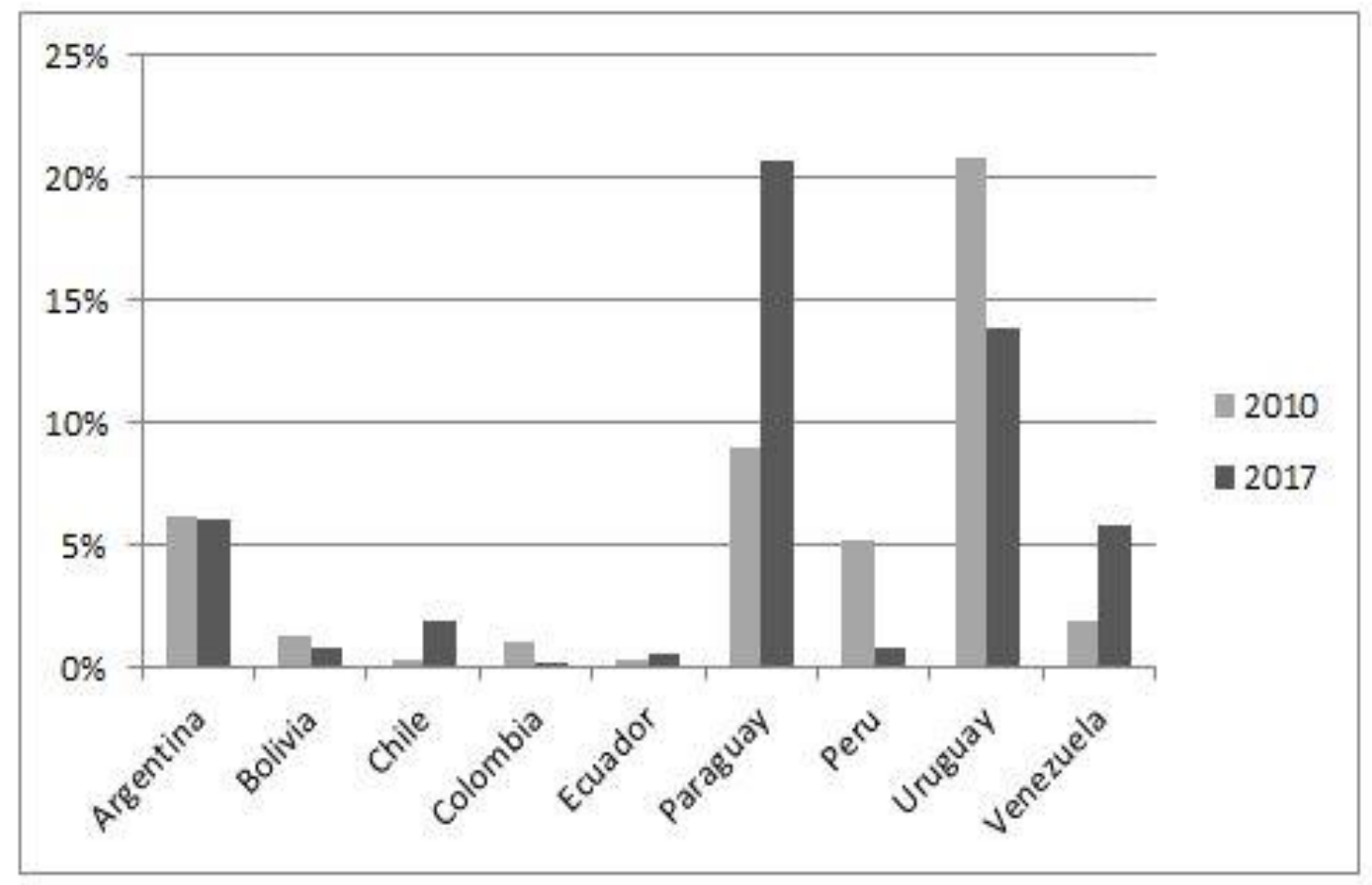

Source: Banco do Brasil (n.d.) and UN Conference on Trade and Development (2018). Note: Data is insufficient for Guyana and Suriname.

Providing another indicator of the low level of regional integration, exports to South America account for a very low share of the GDP of most South American countries, as Figure 04 shows. Bolivia and Paraguay are exceptions because of the former's exports of natural gas and the latter's exports of agricultural goods to Argentina and Brazil. The share of regional exports in GDP for both countries has dropped remarkably during the last decade. For all other countries, the relevance of regional exports has declined from a low level in the late 2000s to a very low level today. With regard to geoeconomic nodality, it is particularly revealing that Brazil's regional exports equaled only two percent of GDP in recent years. It may be true that Brazil's exports to South America are marked by a very high share of manufactured products, which Pinheiro and Gaio (2014) see as an indication of a potential to foster industrialization in Brazil through intraregional trade. This potential however refers to a negligible share of Brazil's total economy. 
Figure 04. Share of regional exports in the GDP of the regional countries

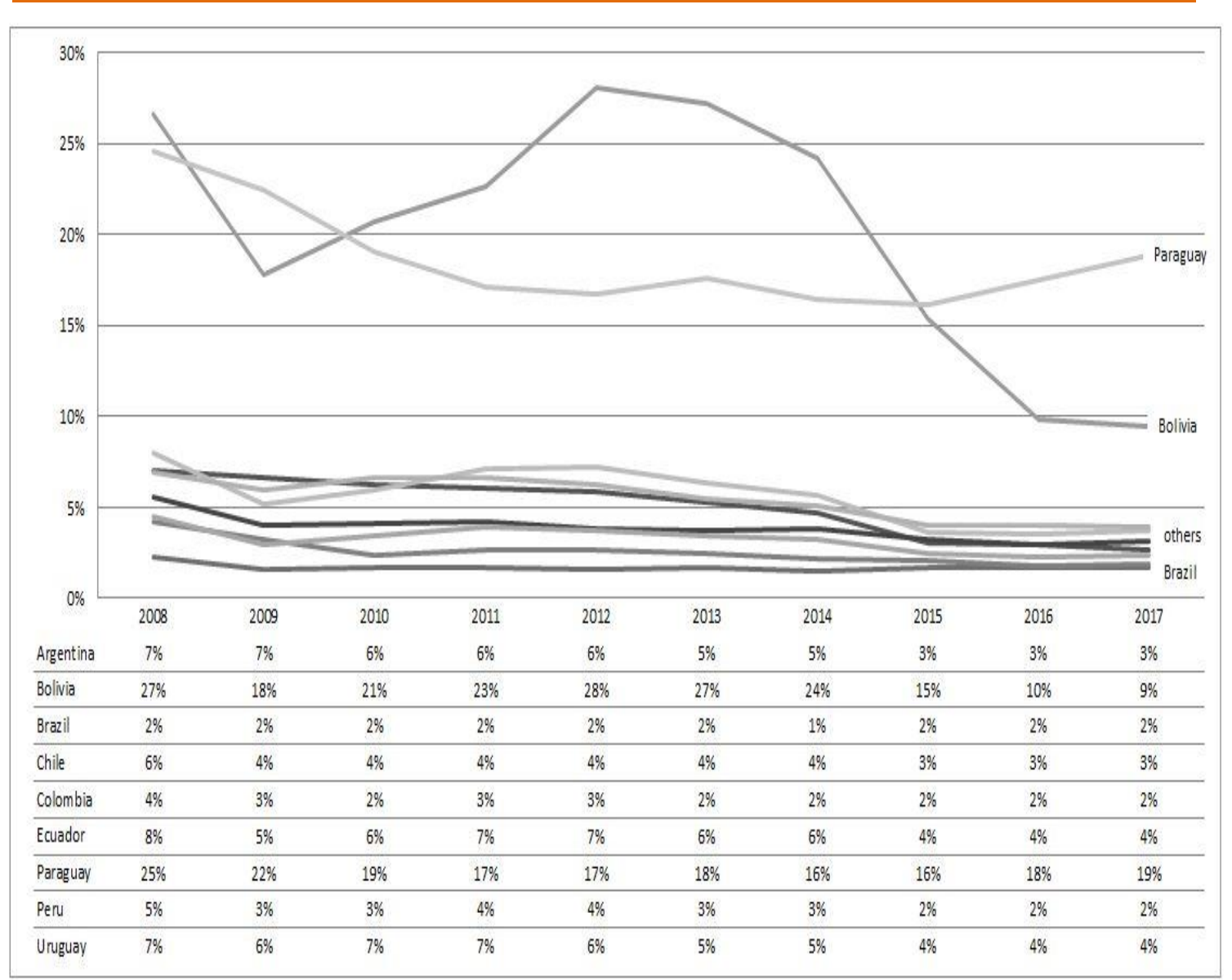

Source: IADB (2018) and World Bank (2018).

Notes: Guyana's regional exports amounted to between 0.1 percent of GDP $(2009$, minimum $)$ and 5.2 percent (2014, maximum). Those of Suriname declined from 2.5 percent (2014, maximum) to 0.1 percent (2017, minimum).

\section{Location and physical barriers}

At first glance, Brazil benefits from a central location in South America. The geographical center of the continent is located at $15^{\circ}$ Southern latitude and $55^{\circ}$ Western longitude, close to Cuiabá. Brazil borders with all regional countries, with the exceptions of Chile and Ecuador. Because of this centrality, trade is not hampered by numerous border stops - the few existing ones do cause serious delays (more on this later) - and there are almost no transit countries that could interfere. 
Still, Brazil is a huge country, as the size comparison with Portugal on the maps below shows. Recife is closer to Monrovia in Liberia (air distance: 3,100 kilometers) than to Quito in Ecuador (4,900 kilometers). Brazil's core zone of population and economic activity - the federal states of Rio de Janeiro and São Paulo - is far away from the Andean countries, Guyana, Suriname, and Venezuela. Road distance from São Paulo to Lima is almost 5,000 kilometers. A rather theoretical road trip from São Paulo to Caracas would mean traveling more than 6,000 kilometers. Even Buenos Aires is 2,250 kilometers away from the Brazilian metropolis. As Map 01 shows, Brazil's population and economic activity is concentrated in proximity to the coast. About 80 percent of the population live less than 200 kilometers away from the Atlantic Ocean6. Agglomerations in the hinterland such as Brasília and Manaus are exceptions. Since maritime transport is not hampered by physical barriers, it is plausible to expect that economic activity in close proximity to the Brazilian coast rather generates maritime than continental links.

Indeed, 48 to 53 percent of Brazil's trade with South America was transported by ocean-bound ships between the mid-2000s and 2017 (up from 37 to 40 percent in the late 1990s) if measured by monetary value; if measured by weight, this figure increases to 63 to 69 percent (up from about 55 percent in the late 1990s), with a drop to 55 to 60 percent in the first half of the $2010 \mathrm{~s}^{7}$. With regard to maritime transport, distance is likely to have a negative impact on regional ties. The main ports of Brazil (Santos) and Peru (Callao) are almost 4,800 nautical miles apart, more than Santos and the harbor of Miami in the US. Guayaquil - the most important harbor of Ecuador - is further away from Santos than Le Havre in France. The only South American urban agglomerations that are closer to Rio de Janeiro and São Paulo than to potential non-South American trading partners are Buenos Aires and Montevideo.

\footnotetext{
${ }^{6}$ Percentages calculated based on data retrieved from the Brazilian Institute of Geography and Statistics <http://www.ibge.gov.br/apps/snig/v1/?loc=0>.

${ }^{7}$ Percentages calculated based on data retrieved from Comex Stat <http://comexstat.mdic.gov.br/pt/home>.
} 
These locational disadvantages are reinforced by physical barriers, which are depicted by Map 02. South America consists of three major physio-geographical regions: the Andes, the highlands of Brazil and Guiana, and lowlands that stretch from the Amazon basin to the Paraguay-Paraná basin to the Patagonian plateau. Along the Amazon River and its tributaries, annual floods hamper transport. They make rivers rise by up to nine meters. Many jetties there cannot be used all year long. Bridges are frequently washed away. Although the Amazon River is navigable from its mouth to Iquitos in Peru (a distance of more than 1,200 kilometers), river transport is risky because of shifting sandbanks. The hot and wet tropical climate accounts for a dense, almost insurmountable vegetation. Transport corridors built through the rainforest are rapidly overgrown by vegetation. Heavy rains amount to 2,500 millimeters a year. They make earth and gravel roads impassable and cause significant damage to more robust infrastructure.

To the southeast of the Amazon basin, there is a plateau landscape at 300 to 500 meters above the sea level: the Brazilian highlands. It is broken up by low mountain systems and deep valleys. The terrain becomes very rough in the federal state of Goiás. Railroads and roads frequently traverse many kilometers to reach destinations only short linear distances apart. For example, in the 1980s, a journey from Rio de Janeiro to Belo Horizonte took an hour by airplane but 14 by rail. Air distance between the two cities is 340 kilometers; the railroad tracks extended 640. The scheduled passenger service between Rio de Janeiro and Belo Horizonte was discontinued in 1990. Given that the Brazilian highlands are tilted north- and westward, rivers rising near their east rim, practically at sight of the Atlantic Ocean, flow inland for hundreds of kilometers before veering north or south. Many of them contain waterfalls, making them useless as a means of transport. 
Map 01. Population density in South America

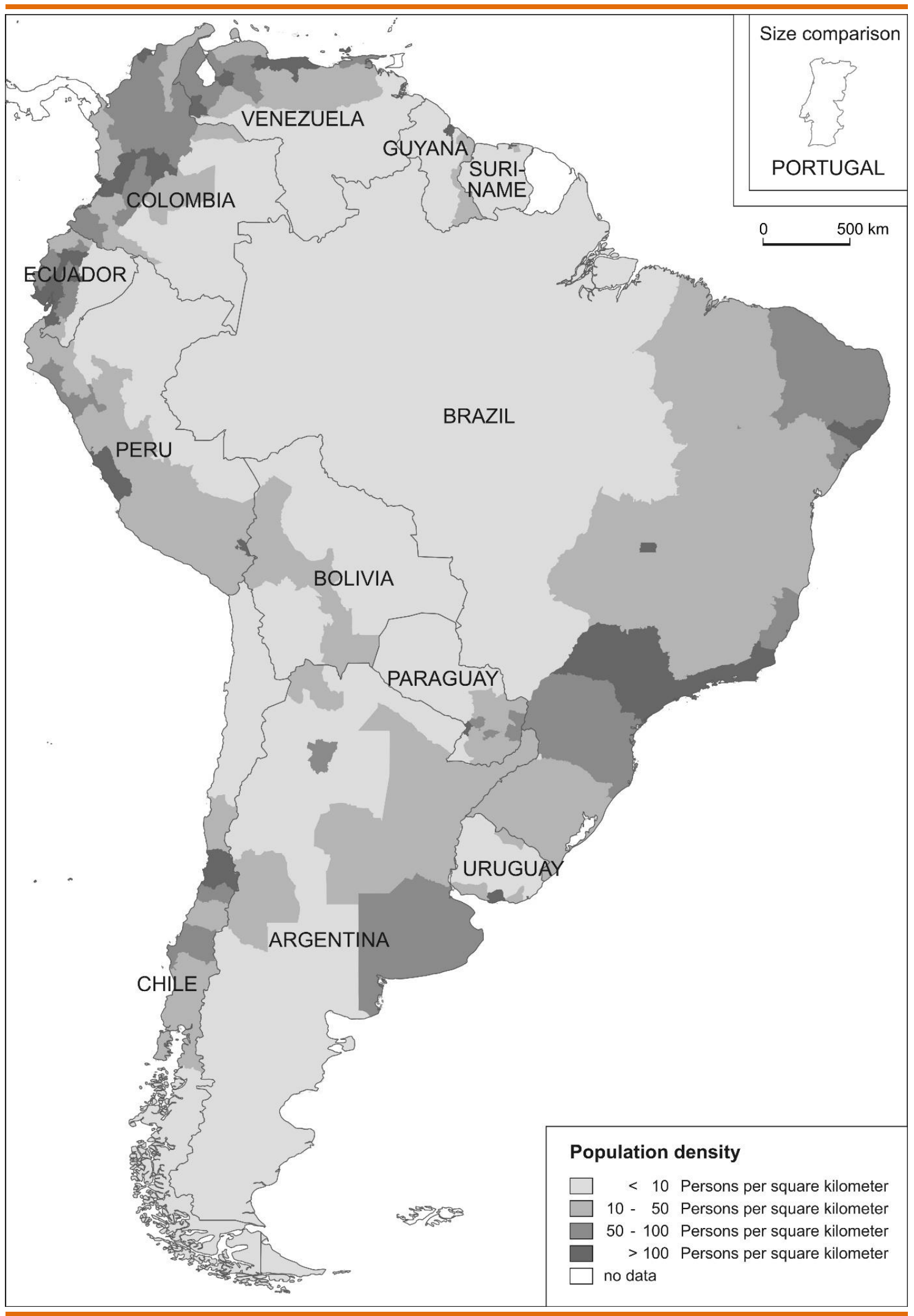

Source: Authors' own compilation based on data obtained from several national statistical offices. 
Map 02. Physical barriers in South America

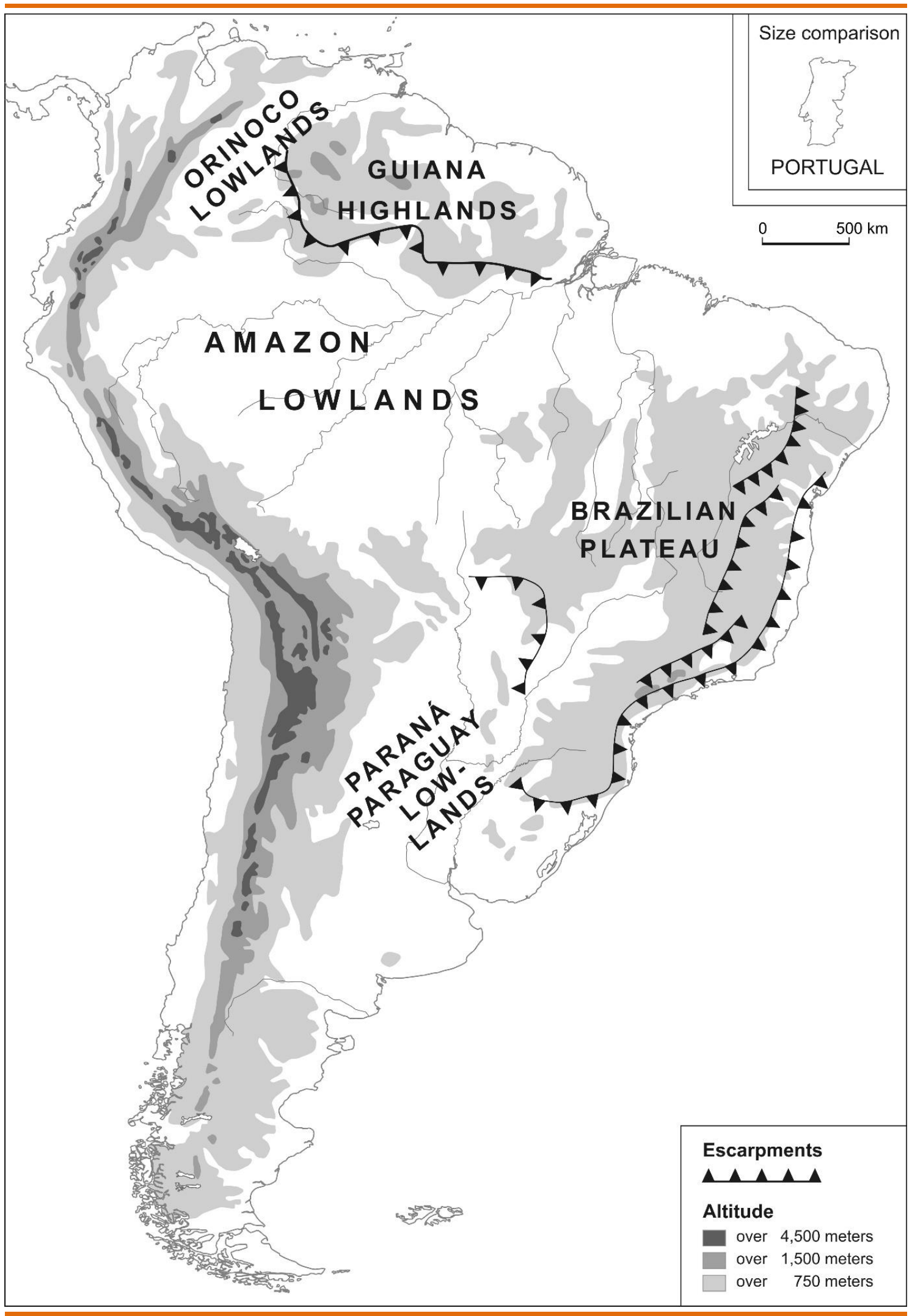

Source: Authors' own compilation. 
In the east, the Brazilian highlands ascend steep escarpments, which link up with the coast. There are only two places where they rise in a single slope and thus somewhat ease movement from the coast to the hinterland: between Paranaguá and Curitiba, and between Santos and São Paulo. Those who have traveled from Santos to São Paulo by road will admit that even this well-developed route appears quite adventuresome. The Rodovia dos Imigrantes, inaugurated in 1974, contains 07 bridges, 11 tunnels, and 44 viaducts. Along with the older Rodovia Anchieta, which also connects Santos to São Paulo, it is considered a masterpiece of civil engineering. In other words, connecting the coastal strip to the hinterland is difficult and expensive. The lack of railroads drives up the cost of transport (WORLD BANK, 2012); so does the fact that there are few alternative ports to Paranaguá and Santos. As a consequence, the queue of trucks waiting to enter Santos sometimes stretches to 40 kilometers, as reported by The Economist (2013).

Further south, the Paraguay-Paraná basin and the Patagonian plateau offer a relative ease of movement that facilitates economic interaction. The river network of the former has been a key axis of expansion into the interior of the continent since colonial times (BROWN, 1979). The Andes, meanwhile, constitute the utmost barrier. They are relatively wide in their central and north reaches (up to 700 kilometers from east to west), and contain several north-to-south ridges as well as extensive plateaus and valleys. The ridges block cross-continental movement of people and goods. The plateaus and valleys host isolated cities such as Bogotá and La Paz. By average, the Southern Andes are lower. Valleys are narrower. The east-to-west extension is about 200 kilometers. Even the Southern Andes are a tremendous obstacle to transport. The route to the main crossover between Argentina and Chile is a slow, gentle incline on the Argentinean side. On the Chilean side, the slope has a far higher grade so that the road consists of a long series of switchbacks to make the descent. Sometimes the path must be closed in winter, when snow blocks its ends and the threat of rockfall is considerable.

\section{Transcontinental infrastructure}

At the beginning of this century, a report by the IADB (2000) showed that trade in South America remained low because of insufficient transport 
infrastructure. According to an ECLAC study published three years later (SÁNCHEZ and TOMASSIAN, 2003), inefficiencies in the transport sector accounted for an extra cost of US\$170 per truck going from Argentina to Brazil, or vice versa. Using routes other than the main arteries added up to 40 percent to transport costs due to the poor quality of these roads. Border stops slowed down transport, taking 30 to 36 hours for trucks going from Brazil to Argentina. Not much has improved as of today. The Economist (2018) recently reported that Latin America and the Caribbean suffer from massive infrastructure deficiencies. Private and public investment in infrastructure stands at 2.5 percent of GDP on average - about a third of the corresponding spending in the Asia-Pacific region. According to Perrotti and Sánchez (2011), an average investment of 6.2 percent of GDP a year is necessary between 2012 and 2020.

Road density in South America is low, boosting the disadvantage that results from Brazil's enormous territorial extension. There are 19 kilometers of road per 100 square kilometers of land in Brazil, 07 in Bolivia, 08 in Paraguay, and 10 in Peru. The corresponding value for the US, which contains vast sparsely populated areas like Brazil, is 67. Europe's largest economies reach values of about 180 (WORLD BANK, 2013). The paved road network, depicted by Map 03, is relatively dense in Brazil's northeast, south and southeast, but it virtually vanishes west of a line from Belém to Campo Grande. West of a line from Manaus to Porto Velho, even sufficiently maintained earth and gravel roads become rare. Only two corridors, partly in miserable condition, cross the Andes: the Inter-Oceanic Highway goes from south Peru via Rio Branco and Cuiabá to southeast Brazil; the Pan-American Highway stretches from the ColombianPanamanian border via Quito and Lima to Santiago de Chile, where it splits into one branch that ends in Southern Chile, and another one that goes to Buenos Aires and from there along the Atlantic Coast to the southern edge of the continent ${ }^{8}$.

\footnotetext{
8The term highway may be misleading for readers used to transport infrastructure in the Global North. In South America, so called highways outside major cities are paved (or unpaved) two-lane roads, whose condition ranges from sufficient to miserable.
} 
Map 03. Road infrastructure in South America

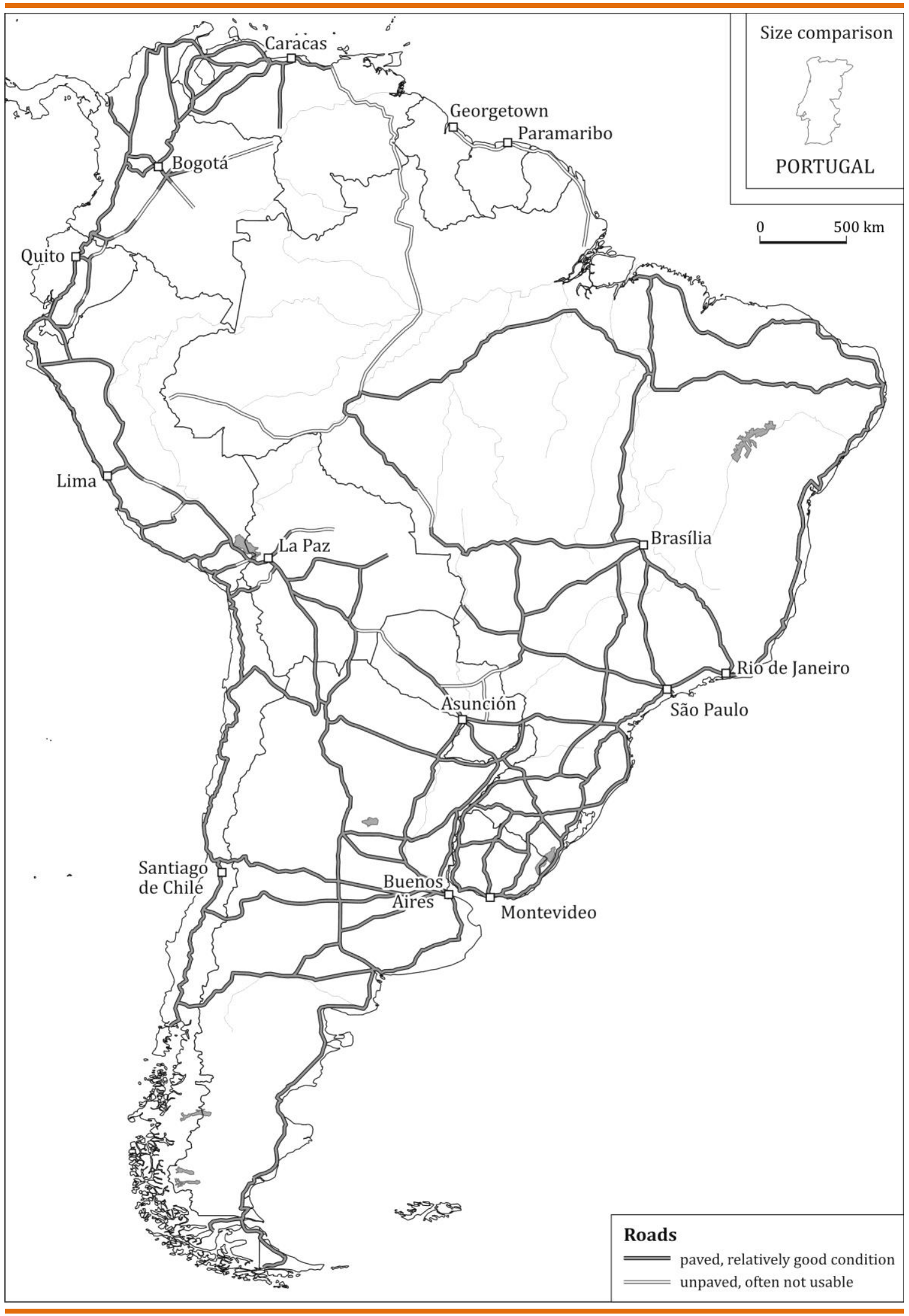

Source: Authors' own compilation. 
Transport by rail is even more difficult because railroad gauges vary. The reason for this is that railroads were initially built for bringing primary-sector goods to the coast. They were not meant to serve as a means of transnational or even transcontinental transport. In the La Plata region, tracks were built with different gauges from the mid-nineteenth century onward so that they could not be used by invading armies. Even the few existing railroad corridors do not allow for efficient transport. The one from Buenos Aires to São Paulo is 300 kilometers longer than the route by road and contains different gauges. The tracks on the Brazilian side date back to the early twentieth century. On the Argentinean side, there is only one bridge across the Paraná River. About a decade ago, transport from Buenos Aires to São Paulo by rail took twice as long as transport by road (LACERDA, 2009). Since then, nothing has changed, as best demonstrated by the failure of Brazil's concession system to attract any investor for building new railroads or rehabilitating existing ones (QUINTELLA, 2016).

China's interest in South American markets has induced a need to better connect to the Pacific Ocean. The People's Republic has announced its support for a yet-to-be-rehabilitated railroad corridor from Chilean and Peruvian ports to Southern Brazil - the Twin Ocean Railroad. The most likely route runs through Bolivia. An alternative corridor passes through Argentina and Paraguay. Considerable financial support has been promised by China (PORTAL PORTUARIO, 2016a, 2016b), but few details have been disclosed and feasibility studies have not been carried out yet (PORTAL PORTUARIO, 2018b). What matters to our analysis is that Chinese-built corridors remain a vision - just like the offer of the Spanish government to finance the Twin Ocean Railroad and a similar proposal by a German-Swiss consortium of private enterprises (PORTAL PORTUARIO, 2018a, 2018c).

The South American ministers responsible for energy, telecommunication, and transport had already agreed in 2000 to coordinate their policies and to foster physical integration 9 . They identified twelve transcontinental development axes and founded IIRSA as a loose intergovernmental initiative, a technical

\footnotetext{
${ }^{9}$ We speak of physical integration - instead of regional integration - so as to stress that these efforts are limited to building transport infrastructure.
} 
forum for cooperation on regional infrastructure that is meant to concentrate on coordinating investment in projects that physically interlink the South American countries. By 2017, the IIRSA portfolio reached US\$ 199 billion and a total of 562 projects, including 153 fully implemented projects for US\$ 48 billion. The development axes Mercosur-Chile and Peru-Brazil-Bolivia are by far the largest with a respective investment share of 24 and 17 percent (COSIPLAN, 2017).

In addition to the aforementioned dominance of single-country projects, the IADB (2008) criticizes that IIRSA has not contributed to lowering regulatory hurdles to cross-border interaction. Political decision makers have remained largely absent from the initiative. In spite of IIRSA's mandate, new financing instruments suited to the particularities of integration projects have not been developed. Financing and implementation remain responsibilities of the member state that hosts the respective infrastructure. States that face severe budget constraints (such as Argentina and Brazil at present) or are close to collapse (like Venezuela) cannot maintain the commitments they have made under better economic conditions.

What is more, Palestini and Agostinis (2015) observe that Brazil's initial commitment to the rehabilitation of transport infrastructure in South America reflected the efforts of the Fernando Henrique Cardoso presidency to physically integrate the entire Brazilian territory in the context of the Avança Brasil agenda. Putting corresponding projects in a continental instead of national frame eased access to financial support from organizations such as ECLAC and the IADB. In other words, the national focus of IIRSA perfectly matches Brazilian interests, which have little to do with regional integration.

One may suggest that trade in services constitutes an alternative to trade in goods for South America - not only because trade in services is not hampered by insufficient rail and road networks, but also because more and more services have become tradable, offering considerable opportunities for emerging economies to provide them to their respective regions, as Turok and Visagie (2019) explain with regard to South Africa. Viola and Lima (2017) consider services exports an opportunity for value chains in Mercosur because they are marked by high valueadded content. Unfortunately, besides that fact that Brazil's share in world services 
trade is marginal, the Brazilian services sector suffers from poor quality and high costs (Arbache, 2016).

Comparing visions and reality of regional cooperation on energy confirms that integration - and thus Brazil's geoeconomic nodality - is mostly rhetoric, except for a few successful projects such as the Itaipú hydroelectric dam. Two years after the Gasoducto del Sur - a giant network of natural gas pipelines across the continent - had first been promoted by Hugo Chávez, Petrobras's president, José Sergio Gabrielli, said it would take 25 to 30 years for a project of this dimension to become operational. The Gasoducto del Sur was later shelved because of Brazil's massive domestic pre-salt discoveries. Brazil's pipeline network has only recently been interconnected nationwide. The focus lies on the exploitation of untapped resources in the Amazon Basin and Atlantic Ocean, not on intraregional trade (ENERGY INFORMATION ADMINISTRATION, 2013). The Bolivia-Brazil pipeline GASBOL connects Santa Cruz with Porto Alegre and São Paulo, reaching a capacity of 31.1 million cbm a day (ENERGY INFORMATION ADMINISTRATION, 2012). Other than that, there are only minor cross-border pipelines, which link Argentina, Bolivia, Chile, and Uruguay, as well as Colombia and Venezuela.

With regard to trade in electricity, the potential of further integration looks equally dim. Experts of the Latin American Energy Organization (OLADE, 2003) argued at the beginning of this century that Argentina and Brazil possess a realistic transfer potential of 5,000 megawatts, which equals only 3.3 percent of Brazil's installed capacity. Argentina and Chile were expected to reach transfers of not more than 500 megawatts; so were Brazil and Uruguay. Colombia and Ecuador as well as Ecuador and Peru, were predicted to transfer 250 megawatts bilaterally ${ }^{10}$. In more recent publications, $\operatorname{OLADE}(2013,2012)$ develops scenarios of regional cooperation and highlights according benefits, but these documents fall short of indicating steps already taken or likely to be taken so as to realize these wishful aspirations. As Scholvin and Betz

${ }^{10}$ These calculations exclude the output of bi- and multinational hydropower stations.

(2020) $14(2) \quad$ - $\quad 0004-26 / 39$


(2019) summarize, various bi- and multilateral hydropower stations have been considered by the regional states, usually for decades and without being implemented.

\section{Public policies}

At least until the impeachment of President Rousseff, Brazil supported the expansion of domestic enterprises into the neighboring countries. The BNDES played the key role in this regard. When Lula came into office, developmentoriented economists affiliated with the Workers' Party (PT) took the lead of the bank. The BNDES more than doubled its investment portfolio (SANTANA, 2011). It sought to strengthen Brazilian enterprises; first of all by supporting the concentration of capital in the hands of a few, creating 'sectoral champions' that were supposed to be internationally competitive (COUTO, 2008). Zibechi (2012) argues that South America - especially Bolivia, Paraguay, and Uruguay - were transformed into economies subordinated to Brazil, into stepping stones for the globalization of these sectoral champions.

Another key means of the BNDES to boost the regional standing of Brazilian companies is the scheme 'BNDES Finem' (BNDES, 2013a). This scheme consists of credit lines directed at specific sectors, including energy and transport. Credits for projects carried out abroad by Brazilian enterprises, covering up to 60 percent of the total costs, are granted under the condition that the respective projects contribute to the economic and social development of Brazil. Since 2003, the BNDES has also participated in projects abroad as a shareholder. Brazilian exports are eased by the scheme 'BNDES Exim' (BNDES, 2013b). The BNDES has given Brazilian exporters proceeds for high value-added industrial sales in Latin America up front since 2011. The bank has also provided open credit lines to states that are certain to spend these credits on Brazilian products. Argentina, for example, received credits of US\$ 1.2 billion from 2005 to 2009, which then went into the pockets of Brazilian construction firms (HOCHSTETLER and MONTERO, 2013). There is not a preference for regional over global expansion, however. The BNDES serves as an agency of the globalization of Brazilian enterprises, not of regional integration (RAMSEY and ALMEIDA, 2010). 
The bank's role now appears to be in a process of redefinition. The BNDES has not only become involved in criminal proceedings related to corruption scandals. Its monetary capacities have also declined significantly because it was ordered to pay back loans to the state during Michel Temer's presidency. Due to new policies, credits provided by the BNDES are now more expensive than private sector credits (TEIXEIRA, 2018). Bolsonaro initially appointed Joaquim Levy as president of the BNDES and Paulo Guedes as minister of the economy. Guedes and Levy are Chicago-trained neoliberal economists, opposed to the proactive economic and developmental policies that marked the BNDES in the era of the PT presidencies. It hence appears highly unlikely that the BNDES will continue to promote integration in South America.

Even before the impeachment of President Rousseff, regional integration advanced much more slowly than envisaged. The BNDES published studies on monetary integration of Argentina and Brazil at the beginning of this century (Giambiagi, 2001). No progress has been made since then. The topic has simply vanished from the debate. A major obstacle to Brazilian investment in South America is double taxation - that is, the levying of a tax by two jurisdictions on the same asset, financial transaction, or income. Argentina, Chile, Ecuador, Peru, and Venezuela have signed agreements with Brazil to avoid double taxation. No such agreements exist between Brazil, on the one side, and Bolivia, Colombia, Guyana, Paraguay, Suriname, and Uruguay, on the other. Mercosur has also failed to lower tariffs on intermediary goods. These have increased since the early 2000s (VIOLA and LIMA, 2017). Regulatory standards and rules of origin are further challenges in the regional community (INTERNATIONAL MONETARY FUND, 2017).

Brazilian investment in its neighboring countries is additionally hampered by insecure currency exchange rates. Between 2008 and 2013, the exchange rate of the Brazilian Real to the Argentinian Peso fluctuated between 1:1.39 and 1:2.66. At the time of this writing, it stood at 1:11.40. One Brazilian Real was worth 0.89 Venezuelan Bolívares in January 2009 but 3.19 in February 2013. Today, Venezuela suffers from hyperinflation ${ }^{11}$.

\footnotetext{
${ }^{11}$ The exchange rates have been calculated online at: <www.x-rates.com>.
} 
What is more, some regional states pursue policies that are counterproductive to regional cooperation. In 2010, 68 percent of Bolivia's natural gas output, representing 80 percent of its natural gas exports, went to Brazil (ENERGY INFORMATION ADMINISTRATION, 2012). The Bolivian government then forced Petrobras to renegotiate its long-term contract in the course of the re-nationalization of the hydrocarbon sector, making the Brazilians pay higher royalties. Given the apparent insecurity involved in trade with Bolivia, a pre-crisis business plan by Petrobras (2011) specifies that imports of Bolivian natural gas will remain constant at 30 million cbm a day until 2020. Conventional production in Brazil is to increase from 55 to 102 million cbm, which does not cover pre-salt sources, whose share in domestic production is to increase from 07 to 31 percent (PETROBRAS, 2013a).

If there were no political uncertainties, Brazil would purchase energy resources in Bolivia, Venezuela, and probably also Argentina instead of developing its own. Argentina used to be an even less secure provider than Bolivia, as demonstrated by the decision of Nestor Kirchner's government to abruptly limit exports of natural gas to Chile in 2004, breaking previously signed contracts. The insecurity of natural gas imports experienced by Brazil and Chile is due to the general political orientation of Argentina (until the 2015 election) and Bolivia, whose governments have strongly interfered with the economy. Brazil's PT also adhered to state interventionism, albeit to lesser extent than practiced Argentina, Bolivia, and Venezuela. We cannot enter into a debate on neoliberal versus state-driven development here, but the previous lines suggest that certain forms of state interventionism, arguably carried out for the sake of national development, work against Brazil's geoeconomic nodality.

\section{Conclusion}

This article dealt with Brazil's role in South America, which we analyzed in the light of the concept of geoeconomic nodality. This perspective advances the state of research because it shows whether rhetoric on regional cooperation and integration translates into reality. Our 
approach is also innovative insofar as it draws attention to neglected causal factors: geographical conditions that interact with public policies. We contend that such causal factors are an important piece of the puzzle that is Brazil's role in South America.

The distinctiveness of our approach becomes particularly clear when compared to Milani, Pinheiro and Lima's (2017) insightful article. They find that cohesion among domestic elites has often been insufficient for Brazil to become a regional leader or paymaster, a graduated power in their terminology. In contrast, our analysis demonstrated that there are structural constraints to Brazil's graduation or regional hegemony - if one considers connectivity and influence in the economic sphere as vital elements of hegemony. We argue, therefore, that Brazil's 'graduation dilemma' also rests on structure - that is, geoeconomic nodality - and not merely on agency.

Brazil's interaction with its region is much less expressive than what one expects from an anchor country, leading area, or regional power. Certainly, the internationalization of Brazilian firms appears to be concentrated on South America. Brazilian construction companies have been involved in important infrastructure projects, benefiting from financial support granted by the BNDES. Still, Brazilian investment in the region is market and resource-seeking. Except for a few cases such as Argentina's automotive sector, it hardly generates value chains, which could trigger development in the neighboring countries. While Brazil is an important trading partner of the Southern Cone (except for Chile), trade with the Andean and Caribbean countries is very limited. Brazil's role as a source of FDI remains negligible, with the exception of Paraguay and Uruguay. Regional exports account for a very low share of the regional GDP. Therefore, we would not even claim that Brazil is the geoeconomic node of the Southern Cone, albeit its relevance there is higher than in South America as a whole.

The concept of geoeconomic nodality rests on four factors (location and physical barriers, the distribution of the population and economic activity, infrastructure for energy and transport, and public policies). First, distances in South America are tremendous. Two major physical barriers, the Andean Mountain Range and the Amazon Rainforest, separate Brazil 
from many of its neighbors. The Brazilian highlands and the landscape configuration of the coast implies that the Brazilian economy is marked by a maritime orientation. Second, the Brazilian population concentrates close to the Atlantic Ocean, compounding the impact of large distances to the neighboring countries. Third, although transport corridors could help to overcome physical barriers, South America suffers from a lack of railroads and roads that bind the regional countries together. IIRSA serves as a means to advance projects of national scope rather than fostering physical integration across borders. Energyrelated infrastructure does not allow for close cross-border ties either. Fourth, public policies interact with natural and man-made geography. This includes the support schemes by the BNDES for Brazil's regional expansion - introduced during the Cardoso presidency, expanded in the PT era and now largely discontinued. Resource nationalism, double taxation, and fluctuating exchange rates work against Brazilian-South American interaction.

We admit that assessments of regional integration in South America - or, more generally, in the Global South - must avoid Euro-centric biases. Because of the different trajectory of economic relations, and the smaller and less developed markets in the Global South, such a comparison would miss the point. Even prosperous emerging economies, such as Brazil until 2014, lack the financial means that initially allowed Germany and France to drive European integration as paymasters (MATTLI, 1999). At this stage, regional integration beyond Europe and North America should focus on developing physical conditions - in particular infrastructure for energy and transport - that improve connectivity and foster regional interdependence. Our analysis demonstrated that there are major obstacles in this regard in South America. Yet, considering budgets constraints due to recurrent economic crises and chronic political instability, as well as the re-orientation of Brazil's economic and foreign policies under Bolsonaro, it is unlikely that regional economic integration will receive any meaningful boost in the coming years.

Revised by Christine Puleo

Submitted on April 30, 2019 Accepted on September 29, 2019 


\section{References}

ARBACHE, Jorge (2016), The contribution of services to manufacturing competitiveness in Brazil. In: Innovation and internationalization of Latin American services. Edited by HERNÁNDEZ, René A.; HUALDE, Alfredo; MULDER, Nanno, and SAUVÉ, Pierre. Santiago: ECLAC. pp. 65-98.

BANCO DO BRASIL (n.d.), CBE: Capitais brasileiros no exterior, 2007 a 2017. Available at $<$ https://www4.bcb.gov.br/rex/cbe/port/ResultadoCBE2017.asp?idpai=CBE\&frame=1>. Accessed on December, 19, 2018.

BNDES (2013a), BNDES Finem. Available at <http://www.bndes.gov.br/SiteBNDES/ bndes/bndes_pt/Institucional/Apoio_Financeiro/Produtos/FINEM/indexhtml>. Accessed on June, 14, 2013.

BNDES (2013b), BNDES Exim. Available at <http://www.bndes.gov.br/SiteBNDES /bndes/bndes_pt/Institucional/Apoio_Financeiro/Produtos/BNDES_Exim/index. html>. Accessed on June, 14, 2013.

BOWN, Chad P.; LEDERMAN, Daniel; PIENKNAGURA, Samuel, and ROBERTSON, Raymond (2017), Better neighbors: toward renewal of economic integration in Latin America. Washington: World Bank. 200 pp..

BROWN, Jonathan C. (1979), A socioeconomic history of Argentina, 1776-1860. Cambridge: Cambridge University Press. 302 pp..

BURGES, Sean W. (2005), Bounded by the reality of trade: practical limits to a South American region. Cambridge Review of International Affairs. Vol. 18, № 03, pp. 437-454.

CASON, Jeffrey W. and POWER, Timothy J. (2009), Presidentialization, pluralization, and the rollback of Itamaraty: explaining change in Brazilian foreign policy making in the Cardoso-Lula era. International Political Science Review. Vol. 30, № 02, pp. 117-140.

CENTRAL INTELLIGENCE AGENCY (2018), The world factbook. Available at $<$ tttps://www.cia.gov/library/publications/the-world-factbook>. Accessed on December, 11, 2018.

CHEN, Lurong and DE LOMBAERDE, Philippe De (2014), Testing the relationships between globalization, regionalization and the regional hubness of the BRICs. Journal of Policy Modeling. Vol. 36, № S1, pp. 111-131.

CHEN, Lurong and DE LOMBAERDE, Philippe (2011), Regional production sharing networks and hub-ness in Latin America and East Asia: a long-term perspective. Integration \& Trade. Vol. 32, № 15, pp. 17-34. 
COHEN, Saul B. (2009), Geopolitics: the geography of international relations. Lanham: Rowman \& Littlefield. 504 pp..

COHEN, Saul B. (1963), Geography and politics in a world divided. New York: Random House. 334 pp..

COHEN, Saul B. (1957), Geography and strategy: their interrelationship. Naval War College Review. Vol. 10, № 04, pp. 01-30.

COUTO, Alessandro B. (2008), A atuação das grandes empreiteiras brasileiras na integração de infraestrutura na América do Sul. In: Financiamento $e$ megaprojetos: uma interpretação da dinâmica regional sul-americana. Edited by VERDUN, Ricardo. Brasília: INESC. pp. 79-88.

COSIPLAN (2017), Cartera de proyectos 2017. Available at $<$ <ttp://www.iirsa.org/admin_iirsa_web/Uploads/Documents/CARTERA_DIGITA L.pdf>. Accessed on December, 20, 2018.

DOCTOR, Mahrukh (2013), Prospects for deepening Mercosur integration: economic asymmetry and institutional deficits. Review of International Political Economy. Vol. 20, № 03, pp. 515-540.

ECLAC (2006), Foreign direct investment in Latin America and the Caribbean 2005. Santiago de Chile: ECLAC. 165 pp..

ENERGY INFORMATION ADMINISTRATION (2013), Country information briefs: Brazil. Available at <http://www.eia.gov/countries/analysisbriefs/brazil/brazil.pdfs. Accessed on December, 12, 2014.

ENERGY INFORMATION ADMINISTRATION (2012), Country information briefs: Bolivia. Available at <http://www.eia.gov/countries/analysisbriefs/Bolivia/bolivia.pdfs. Accessed on December, 12, 2014.

FLEMES, Daniel (2010), Brazil: strategic options in the changing world order. In: Regional leadership in the global system: ideas, interests and strategies of regional powers. Edited by FLEMES, Daniel. Farnham: Ashgate. pp. 105-124.

FLEMES, Daniel and NOLTE, Detlef (2010), Introduction. In: Regional leadership in the global system: ideas, interests and strategies of regional powers. Edited by FLEMES, Daniel. Farnham: Ashgate. pp. 01-14.

FRANKEL, Jeffrey; STEIN, Ernesto, and WEI, Shang J. (1995), Trading blocs in the Americas: the natural, the unnatural and the super-natural. Journal of Development Economics. Vol. 47, № 01, pp. 61-95.

FUNDAÇÃO DOM CABRAL (2011), Transnationality ranking of Brazilian companies: foreign growth and sustainability management. Nova Lima: Fundação Dom Cabral. 155 pp.. 
GIAMBIAGI, Fabio (2001), A moeda comum como base do crescimento do Brasil e da Argentina. Available at <http: //www.bndes.gov.br/SiteBNDES/export/sites/default/ bndes_pt/Galerias/Arquivos/conhecimento/ensaio/ensaio13.pdfs. Accessed on June, 14, 2013.

HOCHSTETLER, Kathryn and MONTERO, Alfred P. (2013), The renewed developmentalist state: the National Development Bank and the Brazil model. Journal of Development Studies. Vol. 49, № 11, pp. 1484-1499.

IADB (2018), INTradebid. Available at <https://intradebid.org/estadisticasindicadores $>$. Accessed on December, 19, 2018.

IADB (2008), Evaluation of IDB action in the initiative for integration of regional infrastructure in South America (IIRSA). Washington: IADB. 42 pp..

IADB (2000), Un nuevo impulso para la integración de la infraestructura regional en América del Sur. Washington: IA DB. 82 pp..

IAPADRE, P. Lelio and TAJOLI, Lucia (2014), Emerging countries and trade regionalization: a network analysis. Journal of Policy Modeling. Vol. 36, № S1, pp. 89-110.

INTERNATIONAL MONETARY FUND, (2017) Cluster report: trade integration in Latin America and the Caribbean. IMF Country Reporter. Washington: International Monetary Fund.

JENKINS, Rhys (2012), China and Brazil: economic impacts of a growing relationship. Journal of Current Chinese Affairs. Vol. 41, № 01, pp. 21-47.

KAMIYA, Marco (2014), Brazilian production sharing and implications for production integration in South America. In: Global value chains and world trade: prospects and challenges for Latin America. Edited by HERNÁNDEZ, René A.; MARTÍNEZ-PIVA, Jorge M., and MULDER, Nanno. Santiago de Chile: ECLAC. pp. 207-243.

KAPPEL, Robert (2012), Zur Ökonomie der Regional Powers. In: Macht, Führung und Regionale Ordnung: Theorien und Forschungsperspektiven. Edited by FLEMES, Daniel; NABERS, Dirk, and NOLTE, Detlef. Baden-Baden: Nomos. pp. 237-264.

KRAPOHL, Sebastian (2019), Games regional actors play: dependency, regionalism, and integration theory for the Global South. Journal of International Relations and Development. DOI: 10.1057/s41268-019-00178-4.

LACERDA, Sander Magalhães (2009), Ferrovias sul-americanas: a integração possível. Revista do BNDES. Vol. 16, № 31, pp. 185-213. 
LIMA, Maria Regina Soares de (2014), A nova agenda Sul-Americana e o papel regional do Brasil. In: El hemisferio en transformación: regionalismo, multilateralismo y políticas exteriores en un entorno cambiante. Edited by HERSHBERG, Eric; SERBIN, Andrés, and VIGEVANI, Tullo. Buenos Aires: CRIES. pp. 211-248.

LIMA, Maria Regina Soares de and HIRST, Mônica (2006), Brazil as an intermediate state and regional power: action, choice and responsibilities. International Affairs. Vol. 82, № 01, pp. 21-40.

MALAMUD, Andrés (2018), Regional organizations and development in Latin America. In: Routledge handbook of Latin American development. Edited by CUPPLES, Julie; PALOMINO-SCHALSHA, Marcela, and PRIETO, Manuel. London: Routledge. pp. 156-167.

MALAMUD, Andrés (2011), A leader without followers? The growing divergence between the regional and global performance of Brazilian foreign policy. Latin American Politics and Society. Vol. 53, № 03, pp. 01-24.

MALAMUD, Andrés (2005), Mercosur turns 15: between rising rhetoric and declining achievement. Cambridge Review of International Affairs. Vol. 18, № 03, pp. 421-436.

MALAMUD, Andrés and GARDINI, Gian L. (2012), Has regionalism peaked? The Latin American quagmire and its lessons. The International Spectator. Vol. 47, № 01, pp. 116-133.

MATTLI, Walter (1999), The logic of regional integration: Europe and beyond. Cambridge: Cambridge University Press. 205 pp..

MILANI, Carlos R. S.; PINHEIRO, Leticia, and LIMA, Maria Regina Soares de (2017), Brazil's foreign policy and the 'graduation dilemma'. International Affairs. Vol. 93, № 03, pp. 585-605.

NOLTE, Detlef (2010), How to compare regional powers: analytical concepts and research topics. Review of International Studies. Vol. 36, № 04, pp. 881-901.

O GLOBO (2018a), Empresas brasileiras apostam em operação no exterior para crescer. Available at <https://oglobo.globo.com/economia/empresas-brasileirasapostam-em-operacao-no-exterior-para-crescer-22815072>. Accessed on December, 18, 2018.

O GLOBO (2018b), Equipe de Bolsonaro estuda transformar Mercosur em área de livre comércio. Available at <https://oglobo.globo.com/economia/equipe-debolsonaro-estuda-transformar-Mercosur-em-area-de-livre-comercio23310470>. Accessed on December, 28, 2018. 
OLADE (2013), Energía: una vision sobre los retos y oportunidades en América Latina $y$ el Caribe. Available at <http://biblioteca.olade.org/ iah/fulltext/Bjmbr/v32_2/cg00058.pdfs. Accessed on January, 12, 2016.

OLADE (2012), UNASUR: un espacio que consolida la integración energética. Available at <http://biblioteca.olade.org/iah/fulltext/Bjmbr/v32_2/old0235.pdfs. Accessed on January, 12, 2016.

OLADE (2003), La situación energética en América Latina. Available at $<$ <ttp://www.iirsa.org/admin_iirsa_web/Uploads/Documents/end_la_situacion_ energetica_en_america_latina.pdf $>$. Accessed on January, 12, 2016.

ØSTERUD, Øyvind (1992), Regional great powers. In: Regional great powers in international politics. Edited by NEUMANN, Iver B.. Basingstoke: St. Martin's Press. pp. 01-15.

PALESTINI, Stefano and AGOSTINIS, Giovanni (2015), Constructing regionalism in South America: the cases of sectoral cooperation on transport infrastructure and energy. Journal of International Relations and Development. Vol. 21, № 01, pp. 46-74.

PERROTTI, Daniel E. and SÁNCHEZ, Ricardo J. (2011), La brecha de infraestructura en América Latina $y$ el Caribe. Available at <https://repositorio.cepal.org/bitstream/handle/11362/6357/1/S110 095_es.pdf>. Accessed on December, 20, 2018.

PETROBRAS (2013a), Plano de negócios e gestão 2013-2017. Available at <http://www.petrobras.com.br/pt/quem-somos/estrategia-corporativa/planode-negocios $>$. Accessed on June, 17, 2013.

PETROBRAS (2013b), Destaques operacionais: produção mensal de óleo e gás natural. Available at <http://www.investidorpetrobras.com.br/pt/destaquesoperacionais/producao/producao-mensal-de-oleo-e-gas-natural-brasil-einternacional/producao-mensal-de-oleo-e-gas-natural-brasil-einternacional.htm>. Accessed on June, 17, 2013.

PETROBRAS (2011), Petrobras divulga plano de negócios 2011-2015. Available at <http:// fatosedados.blogspetrobras.com.br/ wp-content/ uploads/2011/07/apresentacao_plano.pdf>. Accessed on June, 17, 2013.

PINHEIRO, Leticia and GAIO, Gabrieli (2014), Cooperation for development, Brazilian regional leadership and global protagonism. Brazilian Political Science Review. Vol. 08, № 02, pp. 08-30.

PORTAL PORTUARIO (2018a), España se ofrece para financiar proyecto de tren bioceánico. Available at <https://portalportuario.cl/espana-se-ofrece-parafinanciar-proyecto-de-tren-bioceanico>. Accessed on December, 18, 2018. 
PORTAL PORTUARIO (2018b), CAF financiará estudios para implementar corredor bioceánico y puente internacional impulsado por Paraguay. Available at $<$ https://portalportuario.cl/caf-financiara-estudios-para-implementarcorredor-bioceanico-y-puente-internacional-impulsado-por-paraguay>. Accessed on December, 18, 2018.

PORTAL PORTUARIO (2018c), Consorcio suizo-alemán entrega propuesta para desarrollar Tren Bioceánico a Bolivia. Available at $<$ https://portalportuario.cl/consorcio-suizo-aleman-entrega-propuesta-paradesarrollar-tren-bioceanico-a-bolivia > . Accessed on December, 18, 2018.

PORTAL PORTUARIO (2016a), Banco de Desarrollo de China estaría interesado en Corredor Ferroviario Bioceánico a través de Bolivia. Available at $<$ https://portalportuario.cl/banco-de-desarrollo-de-china-estaria-interesadoen-corredor-ferroviario-bioceanico-a-traves-de-bolivias. Accessed on December, 18, 2018.

PORTAL PORTUARIO (2016b), China entregaría crédito por USD 40.000 millones para el tren bioceánico boliviano. Available at <https://portalportuario.cl/china-entregaria-credito-por-usd-40-000-millonespara-el-tren-bioceanico-boliviano>. Accessed on December, 18, 2018.

QUINTELLA, Guilherme (2016), The challenges of integrating the South American railways. Global Railway Review. № 03. Available at $<$ https://www.globalrailwayreview.com/article/27439/the-challenges-ofintegrating-the-south-american-railways>. Accessed on December, 17, 2018.

RAMANZINI JR., Haroldo and MARIANO, Marcelo Passini (2018), As relações com a América do Sul (2008-2015). In: Política externa brasileira: dimensões e estratégias de inserção internacional no pós-crise de 2008. Edited by DESIDERÁ NETO, Walter Antonio; FLORENCIO, Sérgio Abreu e Lima; RAMANZINI JR., Haroldo, and SILVA FILHO, Edison Benedito. Brasília: IPEA. pp. 235-271.

RAMSEY, Jase Ryan and ALMEIDA, André Lúcio Santos de (2010), A ascensão das multinacionais brasileiras: o grande salto de pesos-pesados regionais e verdadeiras multinacionais. Belo Horizonte: Elsevier. 280 pp..

RIGGIROZZI, Pía and TUSSIE, Diana (2012), The rise of post-hegemonic regionalism: the case of Latin America. London: Springer. 189 pp..

SÁNCHEZ, Ricardo J. and TOMASSIAN, Georgina C. (2003), Identificación de obstáculos al transporte terrestre internacional de cargas en el Mercosur. Santiago de Chile: ECLAC. 74 pp.. 
SANTANA, Carlos H. (2011), Conjuntura crítica, legados institucionais e comunidades epistêmicas: limites e possibilidades de uma agenda de desenvolvimento no Brasil. In: Variedades de capitalismo, política $e$ desenvolvimento na América Latina. Edited by BOSCHI, Renato R.. Belo Horizonte: UFMG. pp. 121-163.

SARAIVA, Miriam Gomes (2010), Brazilian foreign policy towards South America during the Lula administration: caught between South America and Mercosur. Revista Brasileira de Política Internacional. Vol. 53, № special, pp. 151-168.

SCHOLVIN, Sören and MALAMUD, Andrés (2014), Is there a geoeconomic node in South America? Geography, politics and Brazil's role in regional economic integration. ICS Working Paper.

SCHOLVIN, Sören and BETZ, Joachim (2019), Energy policy in emerging economies: climate change mitigation under the constraints of path dependence. Lanham: Lexington. 240 pp..

SPEKTOR, Matias (2010), Ideias de ativismo regional: a transformação das leituras brasileiras da região. Revista Brasileira de Política Internacional. Vol. 53, № 01, pp. 25-44.

STAMM, Andreas (2004), Schwellen- und Ankerländer als Akteure einer globalen Partnerschaft: Überlegungen $\mathrm{zu}$ einer Positionsbestimmung aus deutscher entwicklungspolitischer Sicht. DIE Discussion Paper. Bonn: DIE.

TEIXEIRA, Ernani (2018), A crise do BNDES: como evitar sua desmontagem. Available at <https://jornalggn.com.br/noticia/a-crise-do-bndes-como-evitarsua-desmontagem-por-ernani-teixeira-torres-filho>. Accessed on December, 20, 2018.

THE ECONOMIST (2018), Latin America needs an infrastructure upgrade. Available at $\quad<$ ttps://www.economist.com/the-americas/2018/03/10/latin-americaneeds-an-infrastructure-upgrade>. Accessed on December, 17, 2018.

THE ECONOMIST (2013), The road to hell. Available at $<$ http://www.economist.com/news/special-report/21586680-getting-brazilmoving-again-will-need-lots-private-investment-and-know-how-road>. Accessed on January, 05, 2016.

TUROK, Ivan and VISAGIE, Justin (2019), Tradable services, value chains and the Gauteng economy. In: Value chains in sub-Saharan Africa: challenges of integration into the global economy. Edited by SCHOLVIN, Sören; BLACK, Anthony; REVILLA DIEZ, Javier, and TUROK, Ivan. Cham: Springer. pp. 253275.

UN CONFERENCE ON TRADE AND DEVELOPMENT (2018), World investment report 2018: investment and new industrial policies. Geneva: UNCTAD. 45 pp.. 
VIOLA, Eduardo and LIMA, Jean Santos (2017), Divergences between new patterns of global trade and Brazil/Mercosur. Brazilian Political Science Review. Vol. 11, № 03, pp. 01-31.

WORLD BANK (2018), GDP (current US\$). Available at <https://data.worldbank.org/indicator/NY.GDP.MKTP.CD>. Accessed on December, 19, 2018.

WORLD BANK (2013), Road density (km of road per 100 sq. km of land area). Available at <http://data.worldbank.org/indicator/IS.ROD.DNST.K2>. Accessed on May, 15, 2013.

WORLD BANK (2012), How to decrease freight logistics costs in Brazil. Available at $<$ http://siteresources.worldbank.org/INTTRANSPORT/Resources/3362911227561426235/5611053-1229359963828/TP39-Final.pdf>. Accessed on January, 05, 2016.

WORLD BANK (2009), Reshaping economic geography: world development report. Washington: World Bank. 383 pp..

ZIBECHI, Raúl (2012), Brasil potência: entre a integração regional e um novo imperialismo. Rio de Janeiro: Consequência. 346 pp.. 